\title{
PERFORMANCE EVALUATION OF SOLAR COLLECTORS USING A SOLAR SIMULATOR
}

\author{
M. NORHAFANA ${ }^{1}$, AHMAD FARIS ISMAIL ${ }^{1}$ AND Z.A.A. MAJID ${ }^{2}$ \\ ${ }^{I}$ Department of Mechanical Engineering, Faculty of Engineering \\ International Islamic University Malaysia, \\ Jalan Gombak, 53100, Kuala Lumpur, Malaysia. \\ ${ }^{2}$ Faculty of Allied Health Sciences, \\ International Islamic University Malaysia, \\ Bandar Indera Makhota, 25200, Kuantan, Malaysia.
}

norhafana@yahoo.com,faris@iium.edu.my,and zafriazran@yahoo.com

(Received: Oct. 20, 2015; Accepted: Nov. 10, 2015; Published on-line: Nov. 30, 2015)

\begin{abstract}
Solar water heating systems is one of the applications of solar energy. One of the components of a solar water heating system is a solar collector that consists of an absorber. The performance of the solar water heating system depends on the absorber in the solar collector. In countries with unsuitable weather conditions, the indoor testing of solar collectors with the use of a solar simulator is preferred. Thus, this study is conducted to use a multilayered absorber in the solar collector of a solar water heating system as well as to evaluate the performance of the solar collector in terms of useful heat of the multilayered absorber using the multidirectional ability of a solar simulator at several values of solar radiation. It is operated at three variables of solar radiation of 400 $\mathrm{W} / \mathrm{m}^{2}, 550 \mathrm{~W} / \mathrm{m}^{2}$ and $700 \mathrm{~W} / \mathrm{m}^{2}$ and using three different positions of angles at $0^{\circ}, 45^{\circ}$ and $90^{\circ}$. The results show that the multilayer absorber in the solar collector is only able to best adapt at $45^{\circ}$ of solar simulator with different values of radiation intensity. At this angle the maximum values of useful heat and temperature difference are achieved.
\end{abstract}

ABSTRAK: Teknologi Sistem pemanasan air suria merupakan salah satu aplikasi tenaga suria. Penyerap merupakan satu daripada komponen sistem pemanasan air suria. Prestasi sistem pemanasan air suria bergantung kepada penyerap pada pengumpul suria. Di negara di mana cuacanya tidak sesuai, pengumpul suria ujian dalaman dengan penggunaan pensimulasi suria menjadi pilihan. Oleh itu kajian ini dijalankan dengan menggunakan penyerap pelbagai lapisan dalam pengumpul suria pada sistem pemanasan air suria. Kebolehan pengumpul suria juga dinilai menerusi tenaga haba yang terhasil dengan penggunaan penyerap pelbagai lapisan beserta keupayaan pelbagai haluan pensimulasi suria pada beberapa ukuran radiasi suria. Pengumpul suria dengan penyerap pelbagai lapisan diuji dan dinilai dengan mengkaji haba yang boleh dimanfaatkan untuk menghasilkan air panas. Ia dijalankan pada tiga pembolehubah radiasi suria iaitu pada $400 \mathrm{~W} / \mathrm{m}^{2}, 550 \mathrm{~W} / \mathrm{m}^{2}$ dan $700 \mathrm{~W} / \mathrm{m}^{2}$ pada tiga posisi sudut berbeza iaitu $0^{\circ}, 45^{\circ}$ dan $90^{\circ}$. Keputusan menunjukkan kesan sistem pemanasan air suria sememangnya dijangka kerana pengumpul suria memainkan peranan utama apabila ia berupaya dilaraskan pada radiasi solar pelbagai haluan dengan intensiti pensimulasi suria yang berbeza. Pengumpul suria pada pensimulasi suria berfungsi secara optimum pada $45^{\circ}$ dengan nilai intensiti radiasi yang berbeza di mana haba berguna dan suhu yang berbeza diperolehi.

KEYWORDS: solar water heating system; solar collector; multilayered absorber; solar simulator; solar radiation 


\section{INTRODUCTION}

Energy is one of important daily resources in all walks of life [1,2]. There are many types of energy resources in this world and the most common one is electrical energy [3]. Its importance is evident from the fact that if slight changes occur it can directly affect all human activities. This can be seen when there is only a change in the price of energy resources [4], it affects almost all human activities causing political and economic crises $[3,4]$. This is due to the world's energy supply based on diminishing fossil fuels[5]. This resource will begin to decrease starting in 2015 [6]. The impact of burning fossil fuels has also caused airspace to become increasingly polluted and cause global warming [7].

Instead of using fossil fuel as energy sources, another alternative energy that can be used in decreasing the undesirable effects to the environment is solar energy [8]. Solar energy is one of renewable energy that cannot be exhausted and is constantly renewed [9]. It is also considered to be economical, and environment friendly and due to its safety aspects it is worthwhile to be broadly applied and adopted by people. It can be harnessed either directly or indirectly deriving energy from the sunlight [10]. As there has been increase in demand as well as the higher cost of fossil fuels energy especially for domestic use, solar energy on the other hand, can overcome these problems especially in terms of water heating system applications [11].

In countries with unsuitable weather conditions, the indoor testing of solar collectors with the use of a solar simulator is preferred [12]. Solar simulators are generally of two types which are; those that use a point source of radiation mounted well away from the collector and those with large area multiple lamps mounted close to the collector. For this experiment, it focuses more on this second type of solar simulator [6].

By using a solar simulator, the experiment cannot be equated with the actual conditions under daily solar radiation. This is due to the factor of the air temperature and daily solar radiation which are affected by relative humidity or mass of air and also movement of the air that causes heat loss more rapidly through convection. The error in efficiency measured by using a solar simulator as compared to the actual intensity of solar radiation is about $6 \%$. This solar simulator delivers a high heating effect, which is due to the high wavelength of infrared radiation as compared to a halogen lamp [12]. The rise in temperature is directly proportional to the exposure time in the actual situation. However, to look at the changing nature of the solar collector to the intensity of solar radiation, the use of solar simulator is the best comparative method in which its radiation can be set up and which remains constant.

\section{EXPERIMENTAL SETUP}

This experiment is called a multidirectional solar simulator (MSS) experiment. It uses the solar simulator instead of the intensity of the global solar radiation. It has been conducted by three variables of solar radiation that are at $400 \mathrm{~W} / \mathrm{m}^{2}, 550 \mathrm{~W} / \mathrm{m}^{2}$ and 700 $\mathrm{W} / \mathrm{m}^{2}$ at the different positions of angle which are at $0^{\circ}, 45^{\circ}$ and $90^{\circ}$ (see Figs. 1,2 and 3 respectively). The objective of solar simulator experiment is to examine the useful heat of the multilayered absorber (Fig. 4) in solar collector with multidirectional ability of solar simulator at several values of solar radiation. 


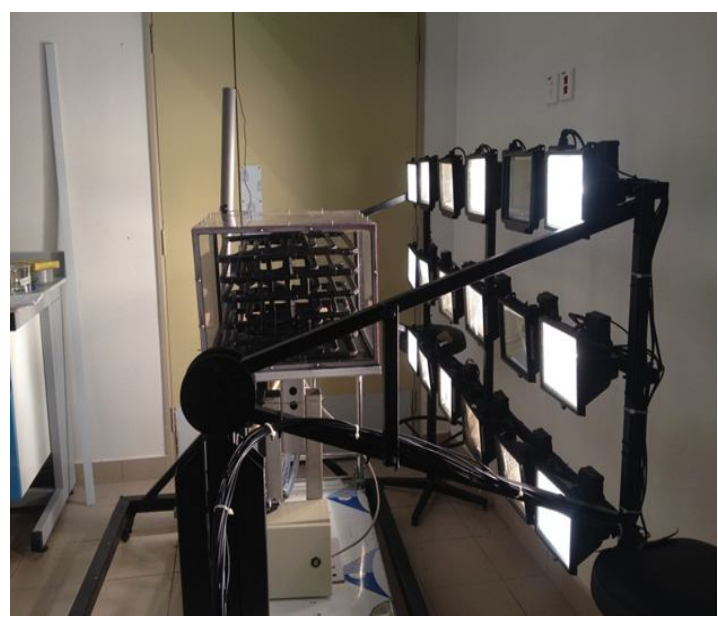

Fig. 1: Experiment setup with solar simulator at angle of $0^{\circ}$.

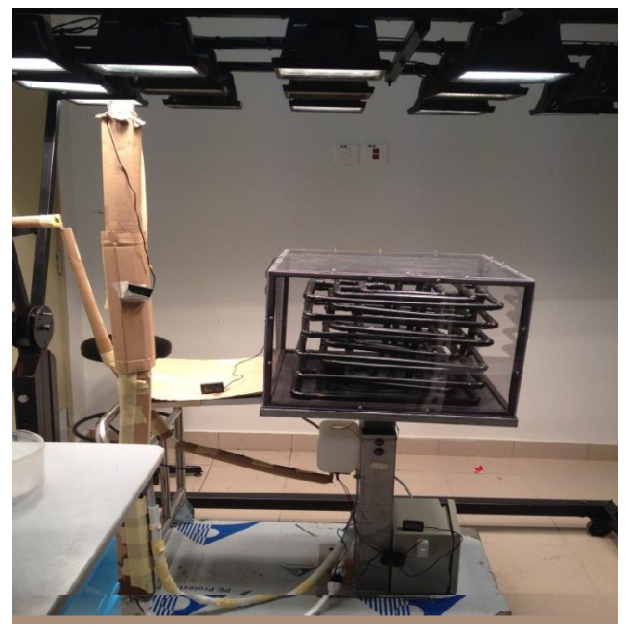

Fig. 3: Experiment setup with solar simulator at angle of $90^{\circ}$.

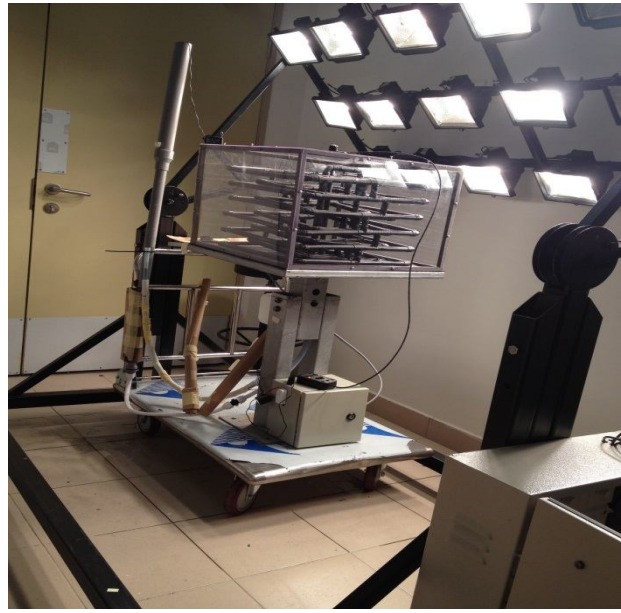

Fig. 2: Experiment setup with solar simulator at angle of $45^{\circ}$.

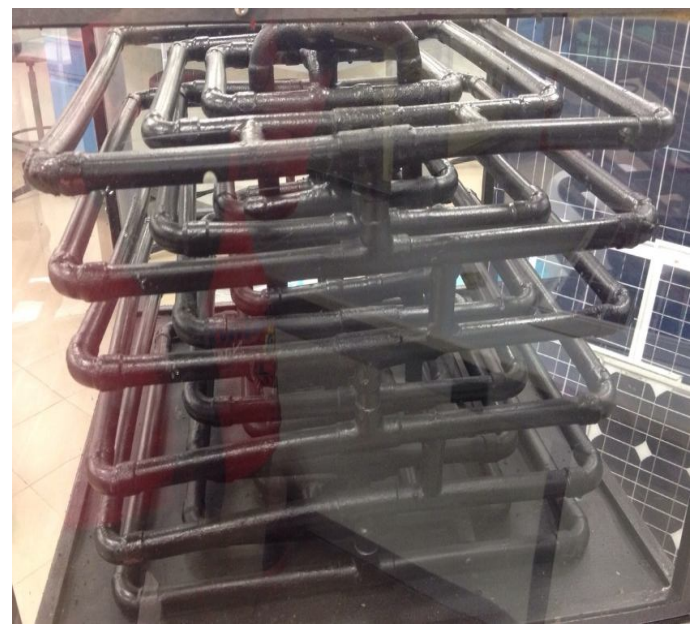

Fig. 4: Multilayered absorber in solar collector.

\subsection{Experimental Materials}

Table 1 below shows the items or materials that are used in the long term experiment. These are solar water heating system, pyranometer, digital temperature sensor, container, container of mineral water, small bench and weighing scale.

\subsection{Experimental Procedure}

The experiment begins with the following procedure. The solar simulator is positioned at of $0^{\circ}$ based on Figure 1 with average value of solar radiation $400 \mathrm{~W} / \mathrm{m}^{2}$ : 
Table 1: The experimental materials, their specifications and functions for MSS experiment.

\begin{tabular}{|c|c|c|c|}
\hline Item & Specification & Function & Total item used \\
\hline $\begin{array}{c}\text { Solar water } \\
\text { heating system }\end{array}$ & $\begin{array}{l}\text { Multilayered absorber (6 layers) } \\
\text { of solar collector }\end{array}$ & To produce hot water & 1 \\
\hline $\begin{array}{c}\text { Solar } \\
\text { simulator }\end{array}$ & $\begin{array}{l}\text { Halogen lamp with } 500 \text { W/unit, } \\
\text { 220-240V/unit }\end{array}$ & $\begin{array}{l}\text { To give the solar } \\
\text { radiation by adjust } \\
\text { the value of radiation }\end{array}$ & 18 \\
\hline Pyranometer & Apogee Logan UT SP-110 & $\begin{array}{l}\text { To measure the } \\
\text { intensity of the } \\
\text { global radiation }\end{array}$ & 1 \\
\hline $\begin{array}{l}\text { Digital } \\
\text { temperature } \\
\text { sensor }\end{array}$ & K-type & $\begin{array}{c}\text { To record the } \\
\text { temperature for each } \\
\text { point }\end{array}$ & 7 \\
\hline Container & $75 \mathrm{~g}$ of container & To collect hot water & 1 \\
\hline $\begin{array}{l}\text { Container of } \\
\text { mineral water }\end{array}$ & $\begin{array}{c}1.5 \text { liter of container of mineral } \\
\text { water }\end{array}$ & $\begin{array}{c}\text { container of mineral } \\
\text { water as a water } \\
\text { supply }\end{array}$ & 1 \\
\hline $\begin{array}{l}\text { Weighing } \\
\text { scale }\end{array}$ & - & $\begin{array}{c}\text { To weigh the mass of } \\
\text { empty container or } \\
\text { with water }\end{array}$ & 1 \\
\hline Small bench & - & $\begin{array}{c}\text { To support water } \\
\text { channel in horizontal } \\
\text { condition }\end{array}$ & 1 \\
\hline
\end{tabular}

1. Mass of empty container, $\mathrm{m}_{\mathrm{c}}$ weighed by using weighing scale and the reading was recorded.

2. Water is filled into the container of mineral water. Water that has been used in this experiment is taken from the water supply.

3. Then, water will be inserted into temporary water storage until the water level at the temporary water storage is at the maximum level and water channel will be positioned as in Fig. 5.

4. The following initial data is recorded:
a. ambient temperature $\left(\mathrm{T}_{\mathrm{at}}\right)$
b. water input temperature $\left(\mathrm{T}_{1}\right)$
c. absorber temperature $\left(\mathrm{T}_{2}\right)$
d. water output temperature $\left(\mathrm{T}_{3}\right)$ (see Figs. 6 and 7 )
e. outer cover temperature $\left(\mathrm{T}_{\mathrm{co}}\right)$
f. inner cover temperature $\left(\mathrm{T}_{\mathrm{ci}}\right)$
g. air temperature at collector $\left(\mathrm{T}_{\mathrm{at}}\right)$
h. solar radiation $\left(\mathrm{S}_{\mathrm{t}}\right)$

5. After the initial reading being recorded, the solar water heating system has been exposed to the solar simulator within $600 \mathrm{~s}$ next reading recorded is at the next interval which is at $600 \mathrm{~s}$.

6 . When reaching the time at $600 \mathrm{~s}$, the reading from ' $a$ ' until ' $h$ ' is recorded.

7. Procedures 2 till 3 are repeated and the reading from 'a' until ' $h$ ' is recorded at 600 $\mathrm{s}$ intervals until the last reading at $3000 \mathrm{~s}$. 
8. Procedures 1 until 7 are then repeated with the solar simulator at the position of $45^{\circ}$ and $90^{\circ}$ (see Figs. 2 and 3 ) respectively.

9. Procedures 1 until 8 are then repeated with the average of solar radiation at 550 $\mathrm{W} / \mathrm{m}^{2}$ and $700 \mathrm{~W} / \mathrm{m}^{2}$.

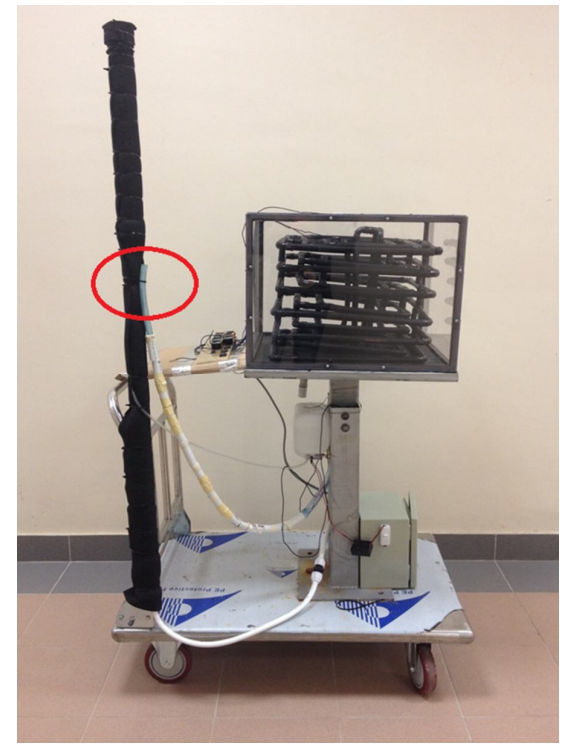

Fig. 5: Location of the clipped water channel.

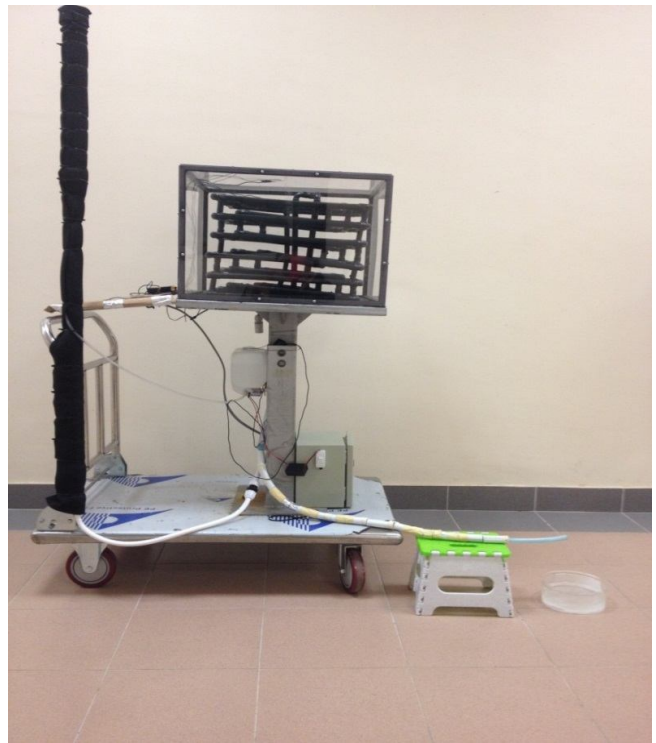

Fig. 6: Position of collecting water from inlet through absorber and outer pipe.

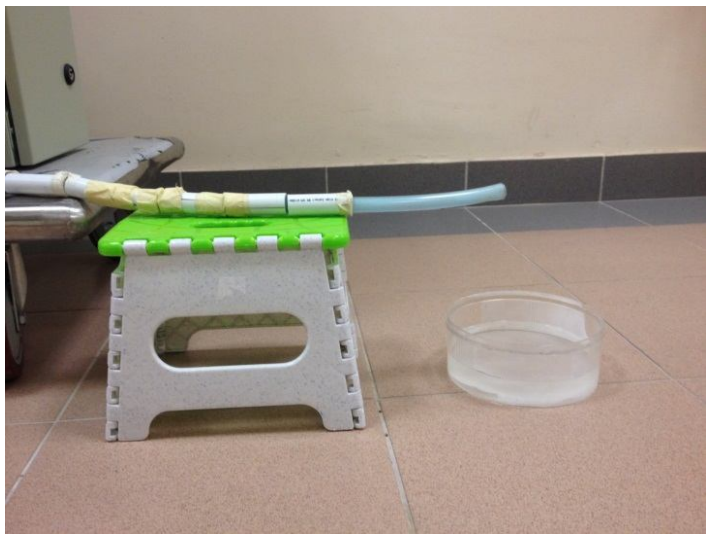

Fig. 7: Position of collecting water from inlet through absorber and outer pipe (zoom in).

\section{MATHEMATICAL MODELLING}

\subsection{Useful Heat}

In this experiment, the important measurement calculated is useful heat from the solar water heating system. Gravity energy is used since no external force such as pump is used in the investigation. 


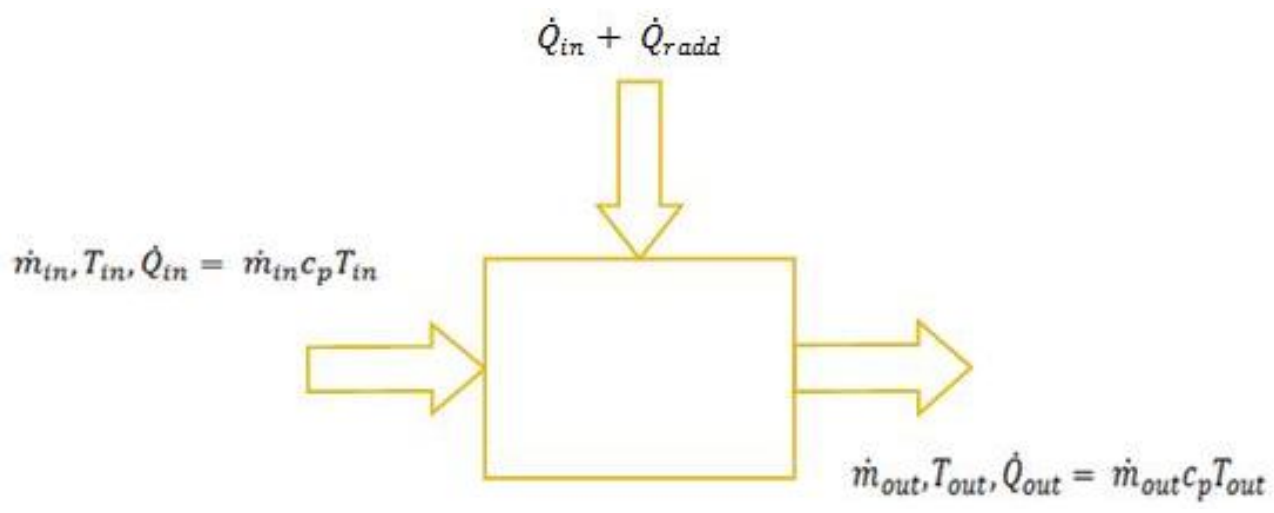

Figure 8: Control volume.

Based on Fig. 8,

$$
\begin{aligned}
\dot{Q}_{\text {in }}+\dot{Q}_{\text {radd }} & =\dot{Q}_{\text {out }} \\
\dot{Q}_{\text {radd }} & =\dot{Q}_{\text {out }}-\dot{Q}_{\text {in }} \\
& =\dot{m}_{\text {out }} c_{p} T_{\text {out }}-\dot{m}_{\text {in }} c_{p} T_{\text {in }}
\end{aligned}
$$

Let assume,

$$
\begin{aligned}
& m_{w}=m_{c+w}-m_{c} \\
& \dot{m}_{w}=\frac{m_{w}}{t} \\
& \dot{m}_{w}=\dot{m}_{\text {in }}=\dot{m}_{\text {out }} \\
& T_{\text {in }}=T_{1} \\
& T_{\text {out }}=T_{3}
\end{aligned}
$$

The useful heat,

$\dot{\mathrm{Q}}_{\text {radd }}=\dot{m}_{w} c_{p}\left(T_{\text {out }}-T_{\text {in }}\right)$

where

$\begin{array}{ll}m_{c} & \text { Mass of empty container }[\mathrm{kg}] \\ m_{c+w} & \text { Mass of container }+ \text { water }[\mathrm{kg}] \\ m_{w} & \text { Mass of water }[\mathrm{kg}] \\ \dot{m}_{w} & \text { Mass flow rate of water }[\mathrm{kg} / \mathrm{s}] \\ \dot{m}_{\text {in }} & \text { Mass flow rate input }[\mathrm{kg} / \mathrm{s}] \\ \dot{m}_{\text {out }} & \text { Mass flow rate output }[\mathrm{kg} / \mathrm{s}] \\ \dot{Q}_{i n} & \text { Rate of input heat transfer }[\mathrm{J} / \mathrm{s}] \\ \dot{Q}_{\text {in }} & \text { Rate of output heat transfer }[\mathrm{J} / \mathrm{s}] \\ \dot{Q}_{\text {radd } \text { eff }} & \text { Useful heat }[\mathrm{J} / \mathrm{s}] \\ c_{p} & \text { Constant pressure specific heat of water }\left[\mathrm{kJ} / \mathrm{kg}{ }^{\circ} \mathrm{C}\right] \\ \mathrm{t} & \text { Total time to collect average water at outlet }[\mathrm{s}]\end{array}$




\section{RESULTS AND DISCUSSION}

In the solar simulator experiment, the useful heat, $\dot{Q}_{\text {radd }}$ values have been compared using a solar simulator (not the real solar radiation), acting as the heat radiator, by determining the value of radiation intensity with $400 \mathrm{~W} / \mathrm{m}^{2}, 550 \mathrm{~W} / \mathrm{m}^{2}$ and $700 \mathrm{~W} / \mathrm{m}^{2}$ from the different angles. This experiment is conducted to prove the capability of the multilayer absorber to absorb heat from multidirectional angle at different values of radiation intensity. The usage of solar simulator in long term period has provided the infrared radiation that causes the air temperature of the solar collector higher compared to the intensity of real solar radiation. Solar simulator with variation average value of radiation such as $400 \mathrm{~W} / \mathrm{m}^{2}, 550 \mathrm{~W} / \mathrm{m}^{2}$ and $700 \mathrm{~W} / \mathrm{m}^{2}$ are used for this experiment. The solar simulator angle is varied as $0^{\circ}, 45^{\circ}$ and $90^{\circ}$ to examine the accumulation of heat through absorber. The time interval of $600 \mathrm{~s}$ is used for each experiment.

Based on Fig. 9 below, it shows the value of useful heat within interval of $600 \mathrm{~s}$ is the highest at angle of $45^{\circ}$ followed by $90^{\circ}$ and $0^{\circ}$ which is the lowest value of useful heat. This also can be seen in Fig. 10 and Fig. 11 where the value of useful heat is the highest at the angle of $45^{\circ}$ for $400 \mathrm{~W} / \mathrm{m}^{2}, 550 \mathrm{~W} / \mathrm{m}^{2}$ and $700 \mathrm{~W} / \mathrm{m}^{2}$ and the lowest is at the angle $0^{\circ}$ (see Fig. 1). In summary, at this angle of $45^{\circ}$ (see Fig. 2), the scattered intensity of the solar simulator is high and wide while the intensity of the solar simulator spread over the entire covering on each layer of the absorber.

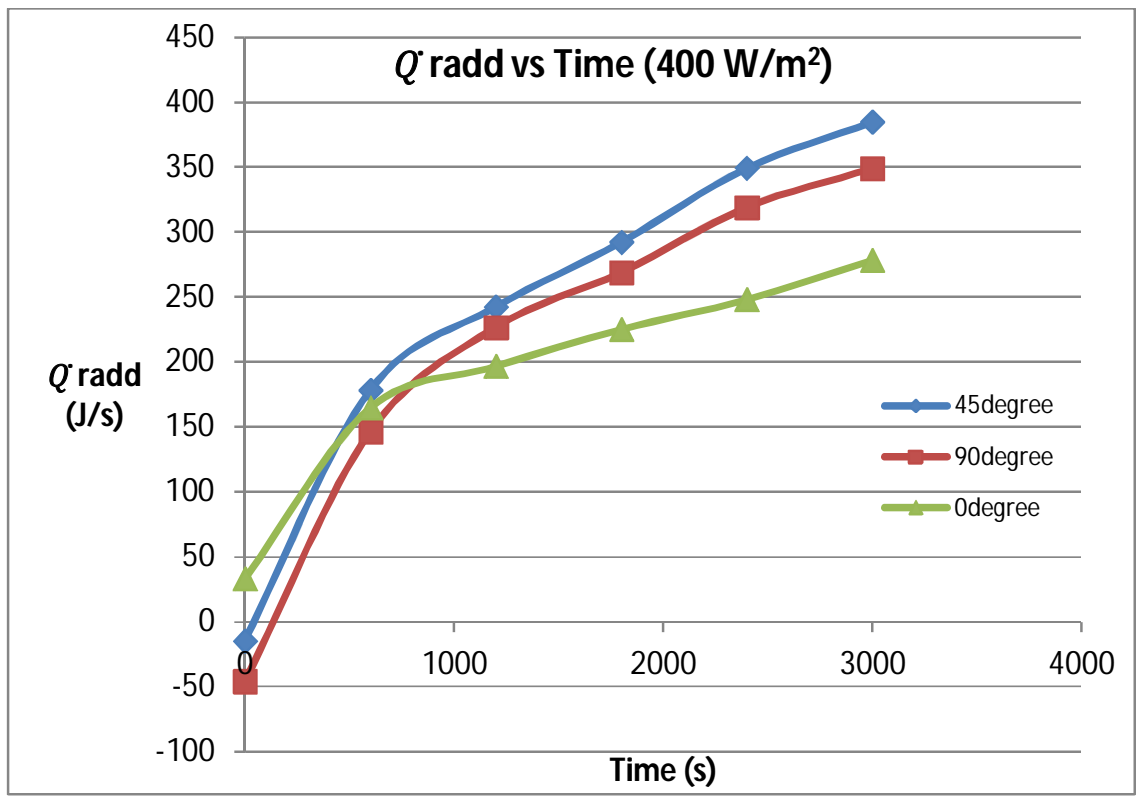

Fig. 9: $\dot{Q}_{\text {radd }}(\mathrm{J} / \mathrm{s})$ versus Time (s) at $400 \mathrm{~W} / \mathrm{m}^{2}$.

At the angle of $90^{\circ}$ (see Fig. 3), only the upper surface of the absorber could receive and absorb the high intensity of the solar simulator. The lower surface also will get the intensity of the solar simulator but its value is not as much as from the angle $45^{\circ}$. Meanwhile, at the angle of $0^{\circ}$, the total of intensity of solar simulator and heat absorbed by the multilayered absorber is the lowest as only side part of the multilayered absorber is exposed to the total of intensity of solar simulator. Other parts of the multilayered absorber, on the other hand get the lowest intensity of solar simulator which gives the lowest value of useful heat. The lowest surface area of the multilayered absorber that is exposed to the solar simulator radiation has given the big impact to the value of heat 
absorbed by the solar simulator radiation and subsequently to the value of useful heat. The high intensity value of solar simulator also affects the value of useful heat because both of these parameter directly affect the heat absorption. This can be proven at the angle of $45^{\circ}$ (see Figs. 9, 10 and 11), in which the maximum value of useful heat at $400 \mathrm{~W} / \mathrm{m}^{2}, 550$ $\mathrm{W} / \mathrm{m}^{2}$ and $700 \mathrm{~W} / \mathrm{m}^{2}$ are respectively at $384.88 \mathrm{~J} / \mathrm{s}, 520.08 \mathrm{~J} / \mathrm{s}$ and $696.34 \mathrm{~J} / \mathrm{s}$. High intensity of solar simulator gives the high value of useful heat. From these three graphs, it could be concluded that the highest value of useful heat is at the angle of $45^{\circ}$ followed by $90^{\circ}$ and $0^{\circ}$ at $400 \mathrm{~W} / \mathrm{m}^{2}, 550 \mathrm{~W} / \mathrm{m}^{2}$ and $700 \mathrm{~W} / \mathrm{m}^{2}$. It means the higher the intensity of solar simulator, the higher value of useful heat could be obtained.

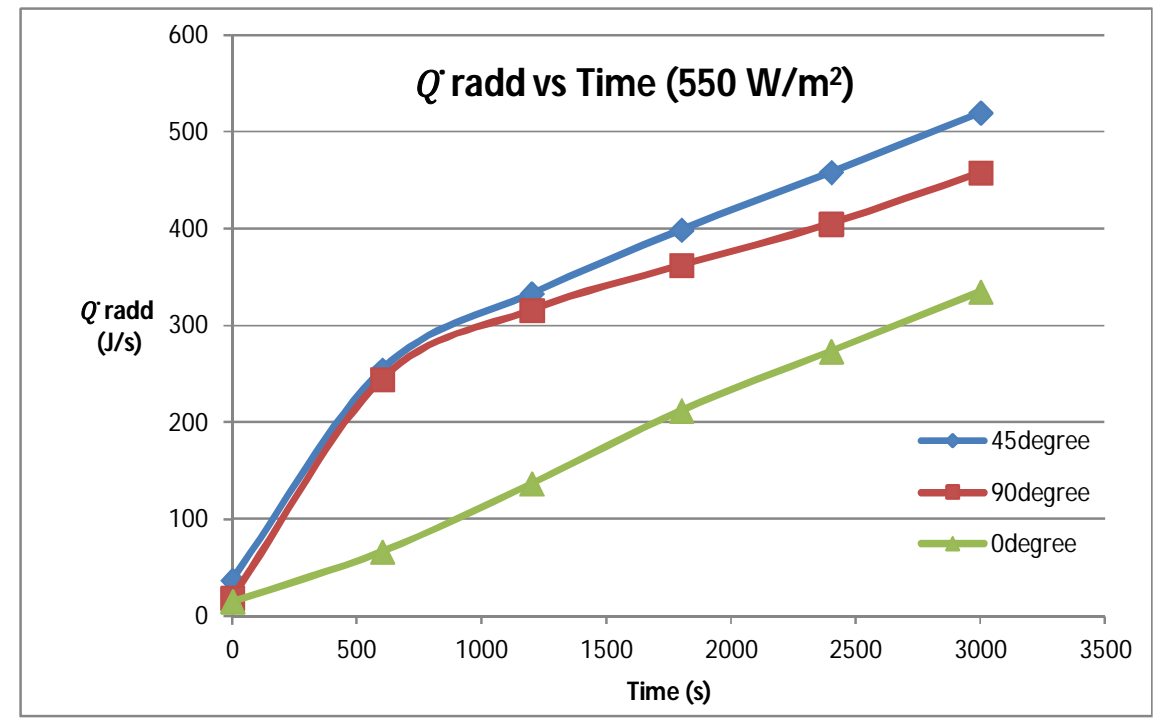

Fig. 10: $\dot{Q}_{\text {radd }}(\mathrm{J} / \mathrm{s})$ versus Time (s) at $550 \mathrm{~W} / \mathrm{m}^{2}$.

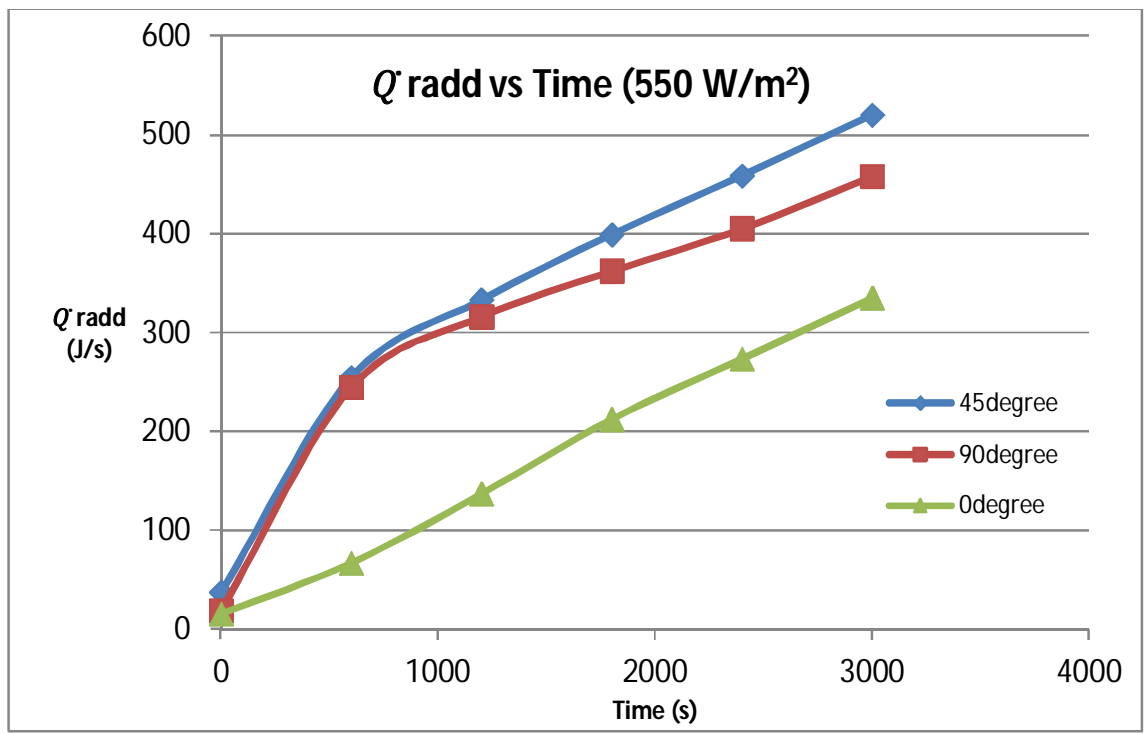

Fig. 11: $\dot{Q}_{\text {radd }}(\mathrm{J} / \mathrm{s})$ versus Time (s) at $700 \mathrm{~W} / \mathrm{m}^{2}$.

Graphs in Figs. 12, 13 and 14 clearly show that the useful heat versus temperature difference at $0^{\circ}$ angle is the lowest value of useful heat. Meanwhile, Fig. 1 shows that the 
light coming from the solar simulator is horizontally converging towards the absorber and solar collector. At this $0^{\circ}$ angle, light can only be focused on the multilayered absorber closest to the solar simulator which is on the side layer. It means that only the side absorber layer can get the highest heat than the other opposite side and the following layer. Subsequently, the heat collected by the absorber is little to be transferred to water and thus the temperature difference will be small as well as useful heat (see Figs. 12, 13 and 14). This can be explained when there is high temperature difference then, the useful heat will also indicate a high value which is directly proportional. Thus, it can be concluded that the temperature difference and the variety of solar simulator angles play a crucial role in this research in which they can be highlighted as benefactor for acquiring difference of useful heat values.

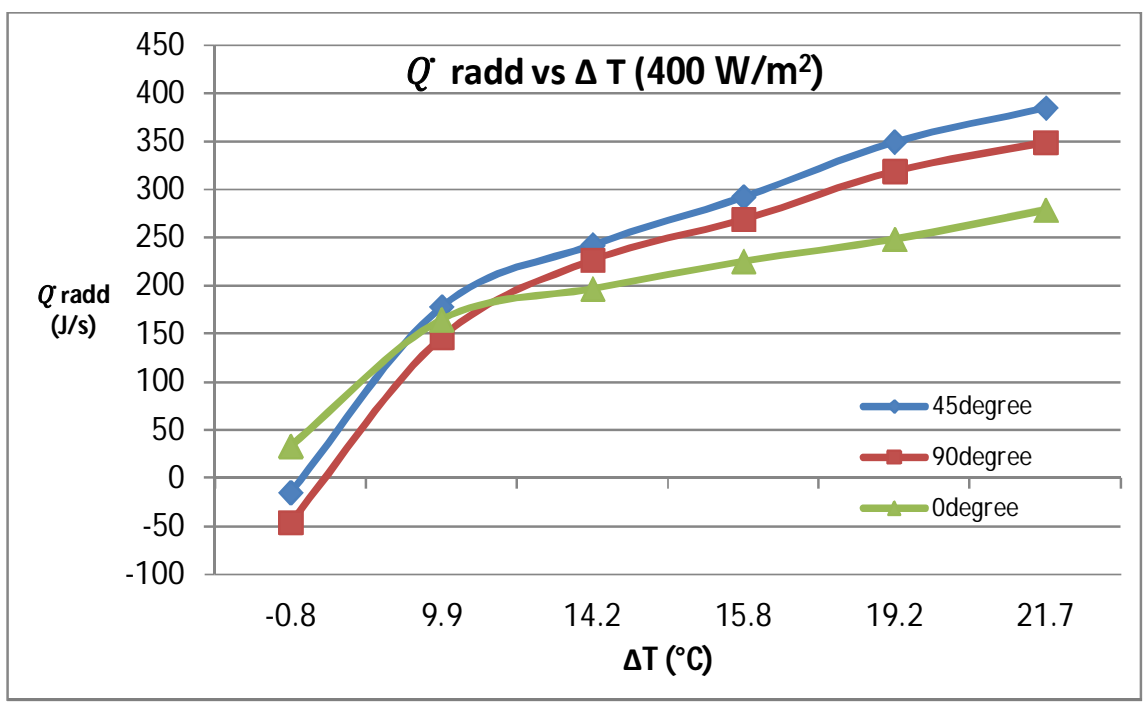

Fig. $12: \dot{Q}_{\text {radd }}(\mathrm{J} / \mathrm{s})$ versus $\Delta \mathrm{T}\left({ }^{\circ} \mathrm{C}\right)$ at $400 \mathrm{~W} / \mathrm{m}^{2}$.

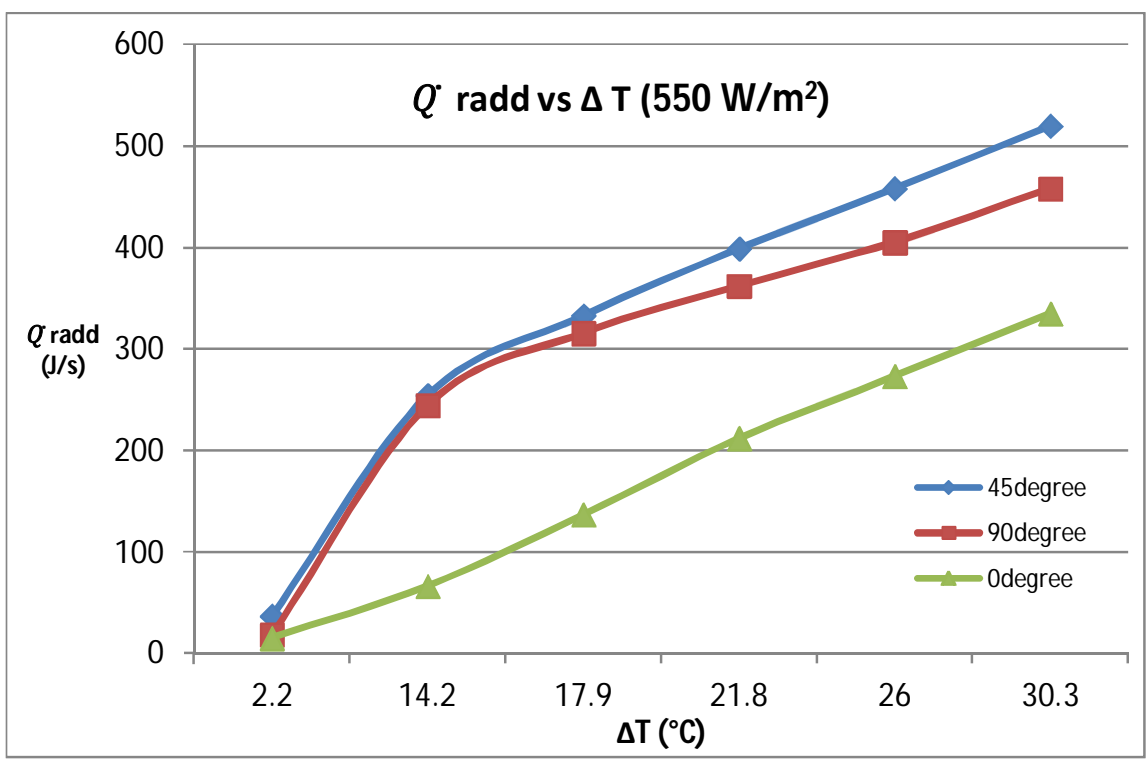

Fig. $13: \dot{Q}_{\text {radd }}(\mathrm{J} / \mathrm{s})$ versus $\Delta \mathrm{T}\left({ }^{\circ} \mathrm{C}\right)$ at $550 \mathrm{~W} / \mathrm{m}^{2}$. 


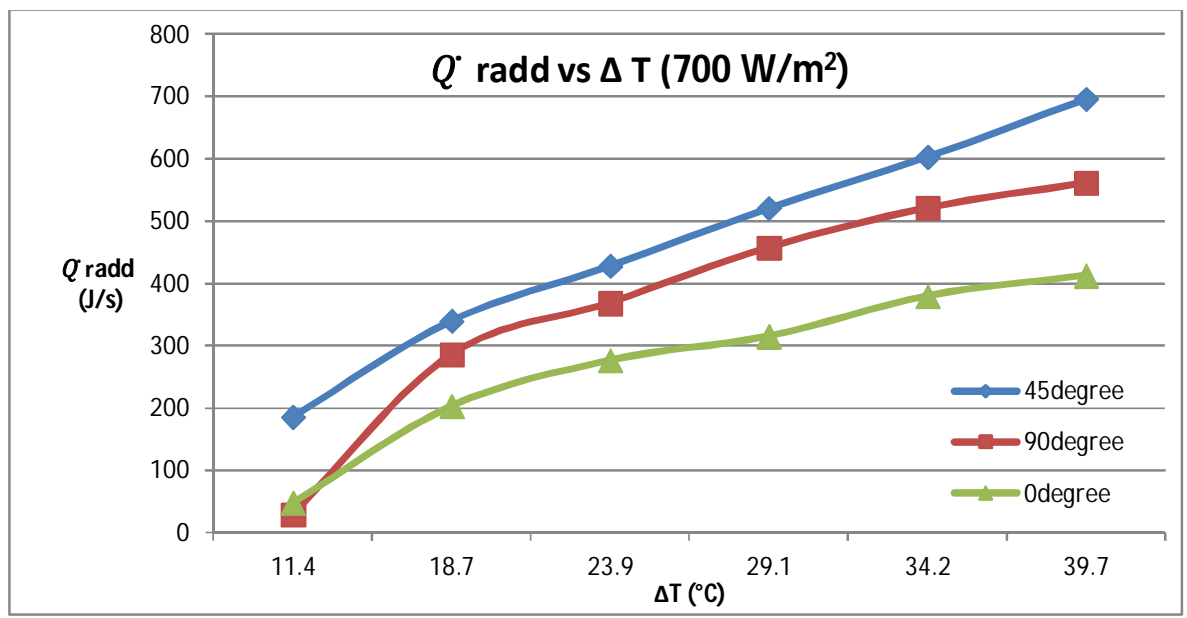

Fig. 14: $\dot{Q}_{\text {radd }}(\mathrm{J} / \mathrm{s})$ versus $\Delta \mathrm{T}\left({ }^{\circ} \mathrm{C}\right)$ at $700 \mathrm{~W} / \mathrm{m}^{2}$.

In addition, the area of absorber is leading to cause the highest of useful heat value. This situation can also be presented through the squares and multilayered absorber itself which it allows the intensity of the solar simulator focusing on the absorber layered by layered. Thus, the collected heat transfer will be high and this can be concluded that there is a linear relation between the area of absorber and the useful heat.

Besides, it can be clearly shown in Figs. 15, 16 and 17 that the temperature differences for the experiment with the angle of $45^{\circ}$ is the highest at $400 \mathrm{~W} / \mathrm{m}^{2}, 550 \mathrm{~W} / \mathrm{m}^{2}$ and $700 \mathrm{~W} / \mathrm{m}^{2}$ followed by experiment with the angle of $90^{\circ}$ and $0^{\circ}$. From figures 15,16 and 17 , the maximum value of temperature difference at $45^{\circ}$ are $21.7^{\circ} \mathrm{C}, 30.3^{\circ} \mathrm{C}$ and $39.7^{\circ} \mathrm{C}$ respectively. The high temperature difference gives the consequence to the heat absorbed by multilayer absorber and it shows that the high ability and performance of the absorber in the solar collector of the solar water heating system.

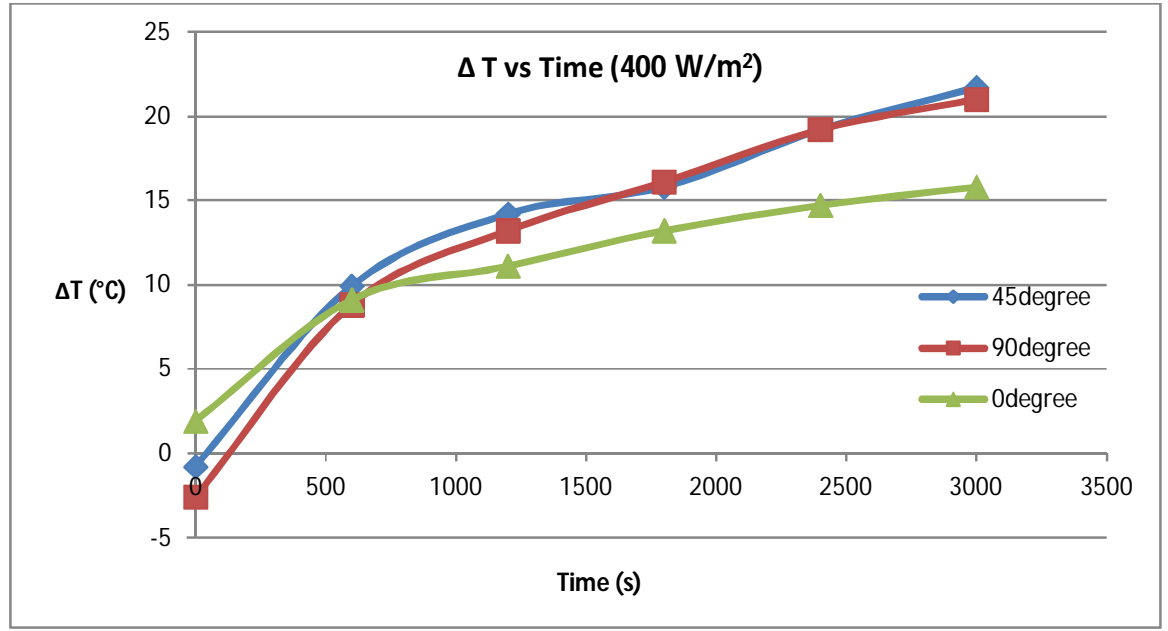

Fig. 15: $\Delta \mathrm{T}\left({ }^{\circ} \mathrm{C}\right)$ versus Time (s) at $400 \mathrm{~W} / \mathrm{m}^{2}$. 


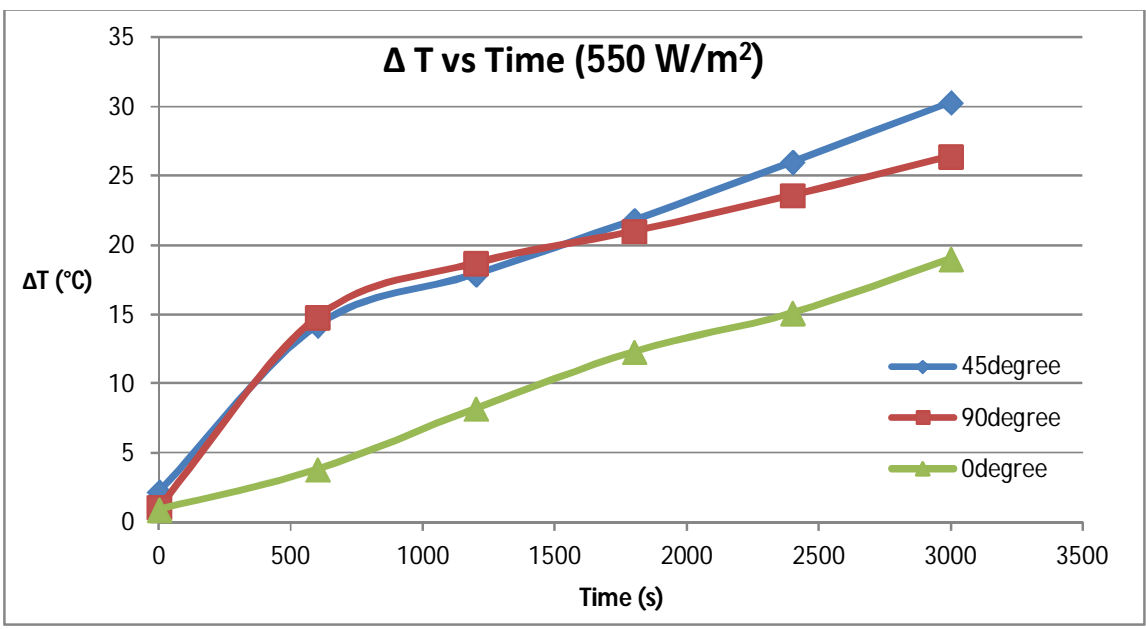

Fig. 16: $\Delta \mathrm{T}\left({ }^{\circ} \mathrm{C}\right)$ versus Time $(\mathrm{s})$ at $550 \mathrm{~W} / \mathrm{m}^{2}$.

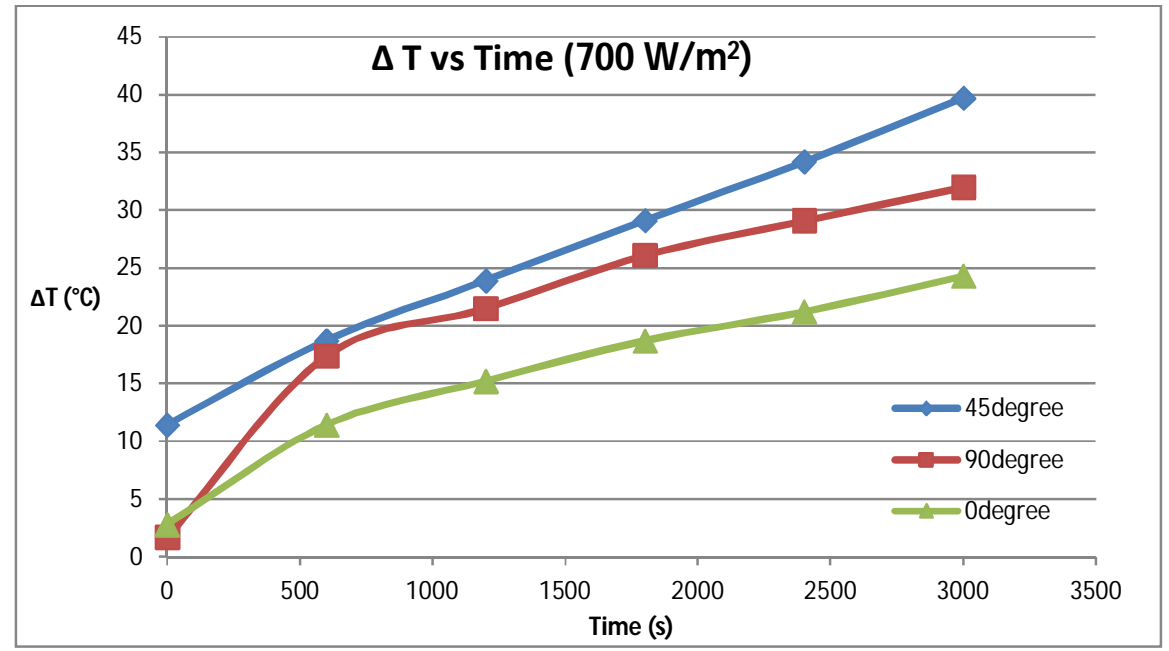

Fig. 17: $\Delta \mathrm{T}\left({ }^{\circ} \mathrm{C}\right)$ versus Time $(\mathrm{s})$ at $700 \mathrm{~W} / \mathrm{m}^{2}$.

The experiment using the solar simulator shows the differentiation and rise of high temperature caused by long wave radiation in the solar collector causing a greenhouse effect which raises the temperature of solar collector higher than the ambient air temperature. Through the experiment using the solar simulator, it can be seen that the temperature is changing more than a real solar radiation. This is due to the solar simulator operation in the infrared wave range is higher compared to the real situation which is using solar radiation.

From the experiment of solar simulation above, it can be concluded that the multilayer absorber in the solar collector is only able to best adapt at $45^{\circ}$ of solar simulator with different values of radiation intensity compared to $90^{\circ}$ and $0^{\circ}$ angles as at this angle, the maximum values of useful heat is achieved and better impact to the solar water heating system. 


\section{CONCLUSION}

As a conclusion, the multilayered absorber inside the solar collector of solar water heating system is proven to play its main role when it is able to adapt in multidirectional solar radiation with different intensity of solar simulator. It can be concluded that the multilayer absorber in the solar collector is only able to best adapt at $45^{\circ}$ of solar simulator with different values of radiation intensity compared to $90^{\circ}$ and $0^{\circ}$ angles. At this angle, the maximum values of useful heat and the temperature difference are achieved resulting in a more efficient solar water heating system.

\section{ACKNOWLEDGEMENTS}

The authors are thankful to the International Islamic University Malaysia and Rad Tec Enterprise for providing laboratory facilities and financial assistance.

\section{REFERENCES}

[1] S. Mekhilef, R. Saidur, and a. Safari, "A review on solar energy use in industries," Renew. Sustain. Energy Rev., vol. 15, no. 4, pp. 1777-1790, May 2011.

[2] C.-D. Ho, T.-C. Chen, and C.-J. Tsai, "Experimental and theoretical studies of recyclic flatplate solar water heaters equipped with rectangle conduits," Renew. Energy, vol. 35, no. 10, pp. 2279-2287, Oct. 2010.

[3] S. Mekhilef, a. Safari, W. E. S. Mustaffa, R. Saidur, R. Omar, and M. a. a. Younis, "Solar energy in Malaysia: Current state and prospects," Renew. Sustain. Energy Rev., vol. 16, no. 1, pp. 386-396, Jan. 2012.

[4] V. Devabhaktuni, M. Alam, S. Shekara Sreenadh Reddy Depuru, R. C. Green, D. Nims, and C. Near, "Solar energy: Trends and enabling technologies," Renew. Sustain. Energy Rev., vol. 19, pp. 555-564, Mar. 2013.

[5] S. Kalogirou, Solar Energy Engineering Processes and Systems. 2009.

[6] Zafri Azran Abdul Majid, M. Y. Othman, M. H. Ruslan, S. Mat, B. Ali, A. Zaharim, and K. Sopian, "Multifunctional Solar Thermal Collector for Heat Pump Application," pp. 342346, 2007.

[7] S. Sadhishkumar and T. Balusamy, "Performance improvement in solar water heating systems - A review," Renew. Sustain. Energy Rev., vol. 37, pp. 191-198, Sep. 2014.

[8] L. Liu, Z. Wang, H. Zhang, and Y. Xue, "Solar energy development in China-A review," Renew. Sustain. Energy Rev., vol. 14, no. 1, pp. 301-311, Jan. 2010.

[9] G. T. Tucho, P. D. M. Weesie, and S. Nonhebel, "Assessment of renewable energy resources potential for large scale and standalone applications in Ethiopia," Renew. Sustain. Energy Rev., vol. 40, pp. 422-431, Dec. 2014.

[10] Y. G. Yin, "Design and Application of Solar Water Heater Intelligent Control System," 2009 Int. Conf. Energy Environ. Technol., pp. 580-583, 2009.

[11] M. Srinivas, "Domestic solar hot water systems: Developments, evaluations and essentials for 'viability' with a special reference to India," Renew. Sustain. Energy Rev., vol. 15, no. 8 , pp. 3850-3861, Oct. 2011.

[12] M. K. A. Sharif, a. a. Al-Abidi, S. Mat, K. Sopian, M. H. Ruslan, M. Y. Sulaiman, and M. a. M. Rosli, "Review of the application of phase change material for heating and domestic hot water systems," Renew. Sustain. Energy Rev., vol. 42, pp. 557-568, Feb. 2015. 